\title{
Tiller survival after drought of 'Grasslands Flecha' tall fescue as influenced by endophyte
}

\author{
C.P. WEST ${ }^{1}$, F. VOLAIRE ${ }^{2}$ and F. LELIEVRE ${ }^{2}$ \\ ${ }^{1}$ University of Arkansas, 1366. W. Altheimer Dr., Fayetteville, AR, 72704 USA \\ ${ }^{2}$ INRA, UMR-SYSTEM, 2 place Viala, 34060 Montpellier, France. \\ cwest@uark.edu
}

\begin{abstract}
'Grasslands Flecha' tall fescue exhibits a partial degree of endogenous summer dormancy, a trait that contributes to plant survival during the long, dry summers of Mediterranean regions. Little is understood of the physiological mechanisms involved in summer survival of summer-dormant fescues and the possible role of endophytes. The influence of infection by endophyte strain AR542 in enhancing summer survival in ungrazed field plots and dehydration survival in greenhouse pots was investigated. Tiller population counts from mid-summer drought and autumn recovery showed no significant endophyte effect on survival. Results from the pot trial showed no differences between endophyte-free and endophyte-infected populations for rate of leaf dry-down, tiller-base water content, membrane leakage, or percentage tiller survival. Endophyte-free Flecha exhibited excellent summer survival, suggesting that endophyte infection may not be as critical for stand survival in summer dormant fescues as it is in summer active types. Infecting Flecha with novel endophytes may provide additional insurance against biotic stresses, thereby offering greater overall fitness across a range of environments.
\end{abstract}

Keywords: drought, tall fescue, tiller survival, membrane damage, senescence

\section{Introduction}

Tall fescue germplasm native to the Mediterranean region generally exhibits less summer activity and more winter growth than germplasm native to central and northern Europe (MacColl $\&$ Cooper 1967). The latter germplasm served as the source of tall fescue originally introduced into North America, New Zealand and Australia. In more recent years there has been interest in developing tall fescue cultivars for the Mediterranean region and in other climatic zones characterised by mild winters and extended summer drought, such as in Australia (Reed 1996), Argentina (Asuero et al. 2002) and the southern U.S. (Malinowski et al. 2005). Such cultivars typically exhibit some degree of summer dormancy, i.e. arrested growth even during occasional rainy periods as a drought avoidance and waterconserving mechanism (Norton et al. 2006a). Endogenous (or obligate) summer dormancy in temperate grasses has been closely linked to enhanced drought avoidance as a mechanism conferring plant survival during long, dry summers (Volaire \&
Norton 2006). Including novel endophytes (those non-toxic to livestock) in new tall fescue cultivars is another recent trend to lower the risk of stand loss due to drought and pests (Bouton et al. 2002). Information is needed on the effects of such endophytes on host water relations and summer drought survival in relation to the summer dormancy trait. Grasslands Flecha was used as an example cultivar exhibiting incomplete summer dormancy (Norton et al. 2006b) for preliminary observations on host summer survival and dehydration tolerance.

\section{Methods}

Grasslands Flecha (Miller 2000) seed, endophyte-free (E-) and endophyte-infected (E+; MaxP ${ }^{\circledR}$ strain AR542) was used to establish plants in a greenhouse trial. Seven-litre pots were filled with $8.7 \mathrm{~kg}$ of loamy-sand soil, into which six seedlings were transplanted in a circle, alternating between verified $\mathrm{E}$ - and E+ seedlings. Transplants were allowed to establish for 6 more weeks, after which watering of pots ceased in six replications, while a seventh replication was kept well watered. There were nine pots per replication, which were sequentially sampled in a time series of progressive dehydration over $37 \mathrm{~d}$. At sampling, shoots were clipped just above the apical meristem for individual plants and manually dissected into four parts: (1) the $2 \mathrm{~cm}$ base of one tiller minus the outer sheath(s) but including the sheath of the youngest fully expanded leaf; (2) another $2 \mathrm{~cm}$ tiller base; (3) senescent shoot tissue; (4) live shoot tissue. Tiller base 1 was weighed fresh, dried at $60^{\circ} \mathrm{C}$ for $24 \mathrm{~h}$, then reweighed to determine water content on a DW basis. Tiller base 2 was floated in $4 \mathrm{~mL}$ deionised water for $24 \mathrm{~h}$ in the dark, then assayed for membrane damage by measuring conductivity before and after boiling (Volaire 2002). The senescent and live shoot tissues were bulked among the three plants comprising an endophyte treatment within each pot, oven dried, and reweighed to determine degree of shoot senescence (proportion of senesced DW to total DW). After sampling, the six replicate pots were re-watered, and live tillers were counted 1 week later. Tiller survival was expressed as a percentage of total tillers, averaged over the three plants per pot of a given endophyte status. Response data were plotted as a function of days of water withholding.

Grasslands Flecha seed, E- and E+ (90\% infection rate), was sown in $2.24 \mathrm{~m}^{2}$ plots in autumn 2004 on a loamy coastal plain soil near Mauguio in southern France. Four blocks were covered with plastic horticultural tunnels to exclude rain during

Table 1 Tiller density and stand cover of non-irrigated endophyte-infected $(E+)$ and endophyte-free (E-) Flecha tall fescue during summer drought and autumn recovery.

\begin{tabular}{|c|c|c|c|c|}
\hline \multirow{2}{*}{ Endophyte status } & \multicolumn{3}{|c|}{-------------------- Tiller populations per m² ------------------- } & \multirow{2}{*}{$\begin{array}{c}\text { Stand cover \% } \\
5 \text { November }\end{array}$} \\
\hline & 5 August & 23 August & 13 September & \\
\hline E- & 1140 & 1320 & 1350 & 93 \\
\hline $\mathrm{E}+$ & 1630 & 1580 & 1360 & 94 \\
\hline$P$ value & 0.053 & 0.099 & NS & NS \\
\hline
\end{tabular}


Figure 1 Indicators of drought stress for $\mathrm{E}+$ and $\mathrm{E}-$ tall fescue cv. Flecha as a function of number of days of water withholding, (a) tiller-base water content, (b) membrane damage coefficient, (c) proportion of shoot senesced, and (d) tiller survival rate after rewatering.

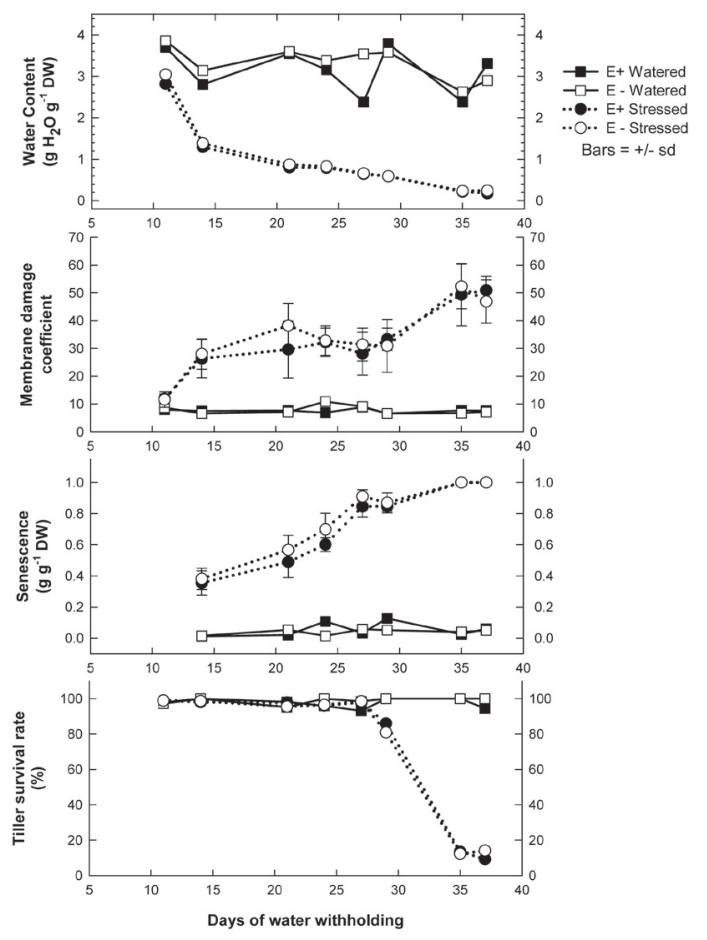

June through September, and one block was left uncovered and irrigated weekly. Tillers were counted in sample rows on 5 August, 23 August, and 13 September during severe drought stress, and stand cover was visually assessed on 7 November, about 7 weeks after rain exclusion stopped and growth resumed.

\section{Results}

Trends in plant responses to duration of water withholding are summarised in Figure 1. There were no significant differences due to endophyte in any measures. Standard deviation bars are shown only in cases where there were apparent differences between endophyte means. Tiller-base water content declined during the dry-down period similarly between E+ and E- plants (Fig. 1a). Membrane damage coefficient (an index of membrane leakage) and proportion of shoot senescence increased over time similarly between E+ and E- plants (Figs. 1b \& 1c). Tiller survival rate was likewise unaffected by endophyte status (Fig. 1d). We performed linear regressions of tiller survival rate vs. tiller-base water content from the last four rewatering days using the six individual replications $(n=24$ per endophyte treatment). We then calculated the predicted water content for each endophyte treatment at which $50 \%$ of the tillers survived. A lower number would indicate greater dehydration tolerance. The result was $0.368 \mathrm{~g} \mathrm{~g}^{-1} \mathrm{DW}$ for $\mathrm{E}+$ and 0.403 for E-, with no significant difference between them.

In the field plots, density of live, green tillers for the non- irrigated tall fescue stands tended (P-values between 0.05 and 0.10 ) to be greater for $\mathrm{E}+$ than E- stands on 5 and 23 August, but was unaffected by endophyte status on 13 September $(\mathrm{P}>0.10)$. Stand cover ratings in November were $93 \%$ and $94 \%$ for $\mathrm{E}-$ and $\mathrm{E}+(\mathrm{P}>0.10)$. Stand counts in August showed a tendency for $\mathrm{E}+$ plants to have retained more active tillers longer into summer than E- plants; however, no initial, pre-drought tiller numbers were available to compare tiller mortality rates. Essentially full and equal stands of $\mathrm{E}$ - and $\mathrm{E}+$ tall fescue were attained during autumn recovery by early November.

\section{Discussion}

The pot trial was designed to determine whether the endophyte used in Flecha tall fescue had any short-term effects on the ability of the tiller growing zones to tolerate a fairly rapid soil dehydration. Under these conditions, no endophyte effects were observed in the rate of drought-stress symptom development or in the critical criterion of drought tolerance used here, tiller survival. The plants were only 12 weeks old at the start of the drydown and were not vernalised, and therefore had not flowered. Flowering has been implicated as a trigger for promoting the summer-dormant trait in cocksfoot (Norton et al. 2006a) and tall fescue (Norton et al. 2006b). The limited volume of the pots, although at $7 \mathrm{~L}$ considered ample when compared to similar published trials (e.g. Elmi \& West 1995), may have limited the ability of 1) potential growth differences in roots due to endophyte presence to be expressed and 2) development of the complement of morphological traits imparting a drought-avoidance strategy characteristic of summer-dormant Mediterranean germplasm (Assuero et al. 2002). Nevertheless, this trial did not reveal any significant ability of the endophyte to directly impact vegetative tiller survival during drought.

The monitoring of field-plot stand density at Mauguio indicated no differences between $\mathrm{E}$ - and $\mathrm{E}+$ for post-drought stand recovery despite more than 3 months of water deficit. This contrasts with results of Malinowski et al. (2005) in which E+ Flecha had 10$50 \%$ greater tiller density than E- Flecha over 3 years in a semiarid zone in Texas, USA; however, E- Flecha stands consistly recovered to near the $\mathrm{E}+$ levels each year, whereas summeractive cultivars disappeared after one year despite endophyte infection. Our results do not rule out possible endophyte benefits on Flecha tall fescue persistence in hotter field environments than Mauguio, France. Flecha apparently has substantial drought tolerance independently of endophyte infection. Endophyte infection may not be as critical for stand survival in summerdormant fescues as in summer-active types thanks to the droughtavoidance mechanism of the host plant. Nevertheless, infecting summer-dormant fescues with novel endophytes may provide additional insurance against herbivory stresses and abiotic extremes, thereby offering greater overall fitness across a wider range of environments.

\section{ACKNOWLEDGEMENTS}

The donation of Grasslands Flecha seed by AgriCom NZ is gratefully acknowledged. Expert assistance by Pascal Chapon and Sabrine Bouchier is deeply appreciated. This work was partially supported by USDA-ARS Specific Cooperative Agreement 6227-21310-007-21S through the Dale Bumpers Small Farm Research Center, Booneville, AR, USA under the auspices of the Institut National de la Recherche Agronomique, UMR-SYSTEM, Montpellier, France. 


\section{REFERENCES}

Assuero, S.G.; Matthew, C.; Kemp, P.; Barker, D.J.; Mazzanti, A. 2002. Effects of water deficit on Mediterranean and temperate cultivars of tall fescue. Australian Journal of Agricultural Research 53: 29-40.

Bouton, J.G.; Latch, G.C.M.; Hill, N.S.; Hoveland, C.S.; McCann, M.A.; Watson, R.H.; Parish, J.A.; Hawkins, L.L.; Thompson, F.N. 2002. Reinfection of tall fescue cultivars with non-ergot alkaloid producing endophytes. Agronomy Journal 93: 567-574.

Elmi, A.A.; West, C.P. 1995. Endophyte infection effects on stomatal conductance, osmotic adjustment and drought recovery of tall fescue. New Phytologist 131: 61-67.

MacColl, D.; Cooper, J.P. 1967. Climatic variation in forage grasses. III. Seasonal changes in growth and assimilation in climate rates of Lolium, Dactylis, and Festuca. Journal of Applied Ecology 4: 113-127.

Malinowski, D.P.; Zuo, H.; Kramp, B.A.; Muir, J.P.; Pinchak, W.E. 2005. Obligatory summer-dormant cool-season perennial grasses for semiarid enviroments of the southern Great Plains. Agronomy Journal 97: 147-154.
Miller, J.E. 2000. 'Flecha' syn Grasslands Flecha. Plant Varieties Journal 13: 31-32.

Norton, M.R.; Lelievre, F.; Volaire, F. 2006a. Summer dormancy in Dactylis glomerata L.: the influence of season of sowing and a simulated mid-summer storm on two contrasting cultivars. Australian Journal of Agricultural Research 57: 565-575.

Norton, M.R.; Volaire, F.; Lelievre, F. 2006b. Summer dormancy in Festuca arundinacea Schreb., the influence of season of sowing and a simulated mid-summer storm on two contrasting cultivars. Australian Journal of Agricultural Research 57: 1267-1277.

Reed, K.F.M. 1996. Improving the adaptation of perennial ryegrass, tall fescue, phalaris, and cocksfoot for Australia. New Zealand Journal of Agricultural Research 39: 457-464.

Volaire, F. 2002. Drought survival, summer dormancy and dehydrin accumulation in contrasting cultivars of Dactylis glomerata. Physiologia Plantarum 116: 42-51.

Volaire, F.; Norton, M.R. 2006. Summer dormancy in perennial temperate grasses.

Annals of Botany 98: 927-933. 